Dobrzanski, P., Bobowski, S., Chrysostome, E., Velinov, E., \& Strouhal, J. (2021). Toward InnovationDriven Competitiveness Across African Countries: An Analysis of Efficiency of R\&D Expenditures. Journal of Competitiveness, 13(1), 5-22. https://doi.org/10.7441/joc.2021.01.01

\title{
Toward Innovation-Driven Competitiveness Across African Countries: An Analysis of Efficiency of R\&D Expenditures
}

\author{
- Pawel Dobrzanski, Sebastian Bobowski, Elie Chrysostome, Emil Velinov, \\ Jiri Stroubal
}

\begin{abstract}
The main goal of this paper is to determine whether R\&D funds are used efficiently in African countries. The innovativeness of a country's economy is nowadays one of the key factors stimulating the economic growth and competitiveness. Becoming more innovative is important in particular for developing countries, whose governments are developing national innovation strategies (NIS) and assuming a steady increase in research and development spending. Efficient innovation policies are creating conditions for enterprise development and the increase of competitiveness of the country. A calculation of R\&D spending efficiency for selected African economies for the years 2009-2017 was carried out using Data Envelopment Analysis methodology, which allows the evaluation of input-output efficiency. Public and private spending on R\&D as $\%$ of GDP was the selected inputs indicator. The model examines three output indicators: the number of patent applications (per million inhabitants), high-technology exports ( $\%$ of export), and number of technical and scientific journal articles (per million inhabitants). Among the analyzed countries, those on the efficiency frontier regarding the use of CRS methodology are South Africa and Tunisia. According to VRS methodology, the most efficient nations are South Africa, Tunisia, and Madagascar. The performed analysis has not confirmed our hypothesis regarding the non-proportional relation between higher $\mathrm{R} \& \mathrm{D}$ spending and innovation outputs. Considering limited innovation capacities across African countries, it appears to be reasonable to increase $\mathrm{R} \& \mathrm{D}$ expenditures gradually to achieve better results on the path toward innovationdriven growth and development.
\end{abstract}

Keywords: competitiveness, DE A methodology, relative efficiency, innovation JEL Classification: R15, O57, O38

Received: August, 2020

1st Revision: January, 2021

Accepted: January, 2021

\section{INTRODUCTION}

It is commonly reported that Research \& Development (R\&D) expenditures boost innovation in an economy. Guellec \& Potterie (2004) have recognized the key importance of R\&D expenditures in fostering knowledge creation and innovation. Moreover, Sinimole \& Saini (2020) have indicated the positive impact of an increase in R\&D expenditures on productivity 
and competitiveness at the national level. $\mathrm{R} \& \mathrm{D}$ expenditures serve as criterion in the assessment of national competitiveness. For instance, total expenditures on R\&D as percent of GDP are included in the Global Competitiveness Index (GCI) developed by the World Economic Forum (WEF) in the "innovation capability" pillar, as well as the "scientific infrastructure" criterion of the World Competitiveness Yearbook (WCY) and the "scientific concentration" criterion of the World Digital Competitiveness Ranking, the latter two of which established by the IMD World Competitiveness Center (IMD WCC). Still, innovation itself does not equate with competitiveness and productivity, as stressed by Clark \& Guy (1998). According to OECD (2010), innovation in broader terms means "the implementation of a new or significantly improved product (...), process, new marketing method or a new organizational method in business practices, workplace organization or external relations." Therefore, innovation itself is associated with productivity which, in turn, relates it to competitiveness (Afzal et al., 2019). The recognition of the link between innovation and competitiveness is of primary importance for developing and catchingup economies, including African countries. This view concurs with studies by Blanco et al. (2016), Kaur \& Singh (2016) and Sokolov-Mladenović et al. (2016), according to which R\&D expenditure is perceived by governments as a trigger of economic growth and competitiveness of a country.

The establishment or revision of Science, Technology and Innovation (STI) policies and strategies has recently become a subject of increasing interest for African governments. The critical role in the promotion of science and technology development across the continent has been played since 2003 by the African Ministerial Council on Science and Technology (AMCOST), established under the auspices of New Partnership for Africa's Development (NEPAD) and the African Union (AU). Africa's Science and Technology Consolidated Plan of Action (CPA) was adopted by AMCOST in 2005 to induce economic growth and improve the lives of African people through building STI capacity and developing related activities in Africa. The AU Assembly of Heads of State and Government has recommended spending no less than 1\% of GDP on R\&D. The crucial question is whether constant increases in spending on $\mathrm{R} \& \mathrm{D}$ provides proportional outputs and increases efficiency. Inefficient R\&D expenditures can be considered as a source of deepening of the innovation gap. Therefore, it is crucial to verify whether an increase in $R \& D$ expenditure provides proportional outputs and increases efficiency.

The objective of the paper is to assess whether R\&D spending in African countries is efficient. Our study fills the research gap in empirical literature dedicated to efficiency of R\&D expenditures in this part of the world. Innovativeness is a broadly discussed issue in research papers; however, an insight into the efficiency of R\&D expenditures deserves special attention. African countries were selected for this analysis, as in previous studies on R\&D efficiency these countries were once omitted, mainly due to the scarcity of data and methodological difficulties. African countries are characterized by diversified science systems which have evolved over the years. Even though national economies differ highly in terms of the level of economic development as well as advances in science and technology, there are some commonalities among national policy and strategy frameworks, such as STI capacities, governance, policy and measurement, R\&D promotion and expenditures, and human resource development.

The rest of the paper is organized as follows. Section 2 presents a review of the literature regarding innovation policies in Africa at the continent-wide, regional and country level, as well as results of studies on innovation efficiency in African countries. Section 3 presents the research 
objectives, methodology and data. Section 4 describes the results and presents a discussion; Section 5 provides the research conclusions.

\section{THEORETICAL BACKGROUND}

\section{Continent-wide and regional innovation policy}

To date there have been few analyses of innovation policies and their impacts in Africa. Muchie et al. (2003) studied the emergence and evolution of national innovation systems in selected African countries, starting with the conceptualization of these systems and continuing through adaptation to specific development challenges of the continent. What has been found is the huge potential of knowledge and ideas rooted across African societies which require higher-level institutions, continent-wide initiatives and more resources to benefit from advances in science and technology and to address key challenges such as indebtedness, poverty, environmental protection and the influences of large multinational enterprises. Lall \& Pietrobelli (2005) studied national innovation systems (NISs) in Sub-Saharan Africa, including Ghana, Kenya, Tanzania, Uganda and Zimbabwe. The researchers point at the lack of appropriate facilities for $\mathrm{R} \& \mathrm{D}$ institutions to identify the technological needs of local industries as well as to transfer and diffuse the requisite technologies to them. The authors argued that some African countries proved to be successful in developing NISs centered around the agriculture sector, in which $\mathrm{R} \& \mathrm{D}$ efforts were supported considerably.

In response to the fourth industrial revolution, African governments are striving to increase $R \& D$ expenditures and extend the technological frontier to meet local opportunities. Among others, investments in high-speed internet have accelerated, enhancing mobility, the digital economy and literacy, with an annual increase recorded in the number of innovation hubs by 40 per cent up to 600 in 2020 (AfDB, 2020). A few African countries, i.e. Kenya, Uganda and South Africa, have already become vital centers of education innovation to increase labor productivity, economic complexity and integrate Africa into a modern knowledge-based economy. For instance, the African Development Bank (AfDB) established a Coding for Employment Program dedicated to the creation of ICT ecosystem which offers infrastructure, soft skill training to youth and networking with global technological frontiers, private sector enterprises and academic centers. According to AfDB, 130 innovation centers and 9 million direct and indirect jobs will be created by 2025 .

The African Union (AU) through its agendas and strategies supports the member states in promoting innovation, science and technology as triggers of long-term growth and development. Since 2007, the African Union Development Agency (AUDA-NEPAD, 2019), the African Union Commission, Regional Economic Communities and the member states have implemented the African Science, Technology and Innovation Indicators Initiative (ASTII) aimed at aforementioned monitoring and data collection on national innovation systems in 43 African countries (AUDA-NEPAD, 2019). In 2014, Science, Technology and Innovation Strategy for Africa 2014-2024 (STISA 2024) was adopted as a framework program for national innovation strategies. Recognizing the role of investment in science, technology and innovation in economic development, the AU Assembly of Heads of State and Government recommended raising $\mathrm{R} \& \mathrm{D}$ expenditures to at least 1 per cent of GDP across African countries. To date, African countries and Regional Economic Communities (RECs), including the Common Market for 
Eastern and Southern Africa (COMESA), the East African Community (EAC), the Southern African Development Community (SADC), the Economic Community of West African States (ECOWAS), the Economic Community of Central African States (ECCAS), as well as the Intergovernmental Authority on Development (IGAD), the Arab Maghreb Union (AMU), and the Community of Sahel-Saharan States (CEN-SAD) institutionalized ASTII in their national innovation systems, however, to a diversified extent.

\section{National innovation policies}

African countries differ significantly in terms of institutionalization of STI policies - while some of them have already established a single strategy and plans of actions in this field, the others designed few separate documents, not necessarily combining innovation with ST policy and system. Importantly, most African countries provided legal frameworks in the studied area (for details, see Table 1).

Tab. 1 - STI policies, strategies and plans in selected African countries. Source: Own elaboration based on NPCA (2014)

\begin{tabular}{|c|c|c|}
\hline Egypt & $\begin{array}{l}\text { Developing Scientific Research Plan } \\
(2007-2016)\end{array}$ & $\begin{array}{l}\text { - improvement of S\&T capabilities, } \\
\text { restructuring its governance and } \\
\text { promotion } \\
\text { - S\&T cooperation with developed } \\
\text { countries }\end{array}$ \\
\hline Ghana & $\begin{array}{l}\text { National Science, Technology and } \\
\text { Innovation Policy (2010) }\end{array}$ & $\begin{array}{l}\text { - promotion of competitiveness and } \\
\text { employment in productive sectors of } \\
\text { the economy } \\
\text { - enhancing industrialization and the } \\
\text { quality of life through innovation } \\
\text { - promotion of information society } \\
\text { and sustainability } \\
\text { - expanding infrastructure } \\
\text { - commercializing research results }\end{array}$ \\
\hline Kenya & $\begin{array}{l}\text { ST\&I Policy and Strategy (2007- } \\
\text { 2012) Kenya Vision } 2030\end{array}$ & $\begin{array}{l}\text { - institutional re-engineering } \\
\text { - strategic resource mobilization } \\
\text { (human capital, education, } \\
\text { infrastructure, R\&D) } \\
\text { - technology and knowledge } \\
\text { governance (S\&T collaboration and } \\
\text { partnerships, transfer and diffusion, } \\
\text { intellectual property) }\end{array}$ \\
\hline Mozambique & $\begin{array}{l}\text { Mozambique Science, Technology } \\
\text { and Innovation Strategy (2006- } \\
\text { 2016) }\end{array}$ & $\begin{array}{l}\text { - promotion of SRI in the industry and } \\
\text { public sector, technology transfer } \\
\text { - development of human capital, } \\
\text { infrastructure and institutions of S\&T } \\
\text { system }\end{array}$ \\
\hline
\end{tabular}




\begin{tabular}{|l|l|l|}
\hline South Africa & $\begin{array}{l}\text { Ten-Year Innovation Plan: } \\
\text { Innovation Towards a Knowledge- } \\
\text { Based Economy (2008-2018) }\end{array}$ & $\begin{array}{l}\text { - designing the national system of } \\
\text { innovation to build foundations of } \\
\text { the innovation-driven economy, } \\
\text { including the key challenges: energy, } \\
\text { space, security, social dynamics, } \\
\text { biotechnology and pharmaceuticals, } \\
\text { climate }\end{array}$ \\
\hline Uganda & $\begin{array}{l}\text { National Science Technology and } \\
\text { Innovation Plan 2012/13-2017/18 }\end{array}$ & $\begin{array}{l}\text { - reduction of absolute poverty } \\
\text { through transformation into an } \\
\text { industrial and innovation-led economy } \\
\text {-inclusion in the global trade and } \\
\text { development processes }\end{array}$ \\
\hline
\end{tabular}

Although African countries differ significantly in terms of the nominal size and the structure of the economy, the level of the income per capita and growth rates, among the key issues addressed by the science, technology (and innovation) strategies/program/plans, there are the development of STI infrastructure and capabilities, STI policy and governance, development of human capital, promotion and increase in R\&D spendings.

In terms of STI governance in Africa, it should be stressed that the issues related to technology, science, and innovation policies are frequently addressed by the Ministry of Education (Cape Verde, Egypt, Angola, Gabon, Malawi, Kenya, Namibia and Mali), department of communication (Lesotho and Tanzania), while in case of Uganda National Council for Science and Technology is subordinated to the Ministry of Finance Planning and Economic Development NPCA (2014). In most African countries, STI policy is designed within the triangle: ministries-departmentsagencies, less often public research institutes and higher education institutions are also involved. The supportive role in this field is played by the United Nations Educational, Scientific and Cultural Organization (UNESCO), as well as continental and regional agencies and bodies such as the African Technology Policy Studies (ATPS), African Science Academic Development Initiative (ASADI), Institute for Economic Research on Innovation (IERI) and the Centre for Research on Science and Technology (CREST). For instance, Burundi, Botswana, Lesotho, the Democratic Republic of Congo, Namibia, Nigeria, Togo, Malawi, Senegal, Zambia and Zimbabwe consulted UNESCO when formulating STI policy, whereas South Africa consulted the Organization for Economic Cooperation and Development (OECD). Noteworthy, some African countries adopted the concept of the national system of innovation (NSI) when formulating/restructuring STI policies, e.g. Egypt, Ghana, Nigeria and South Africa.

\section{Studies on innovation efficiency for Africa}

Analyses of efficiency of $\mathrm{R} \& \mathrm{D}$ expenditures using the data envelopment analysis (DEA) methodology gain more popularity nowadays. Depending on the set of variables and models, valuable conclusions and recommendations may be provided. However, there is a large gap in empirical studies dedicated to the efficiency of R\&D spendings in African economies. Nasierowski \& Arcelus (2003) investigated the efficiency of national innovation system (NIS) of 46 countries, recognizing differences in efficiency and its components, ie. scale and congestion, 
as a trigger of the supposed reduction of productivity growth. An assessment of impacts of R\&D on country's productivity led to conclusion that most analysed economies operate under VRS. Authors indicated a kind of dichotomy in respect of individual countries' commitment to technological effort, manifesting either by overinvestment in selected technological domains, impacting negatively their overall efficiency, or underinvestment in $\mathrm{R} \& \mathrm{D}$, resulting in decreasing returns. Among studied economies there was South Africa which, according to authors, overinvested in certain technological domains, influencing its overall efficiency negatively. Cullmann et al. (2009), using intertemporal frontier estimation, analysed relative efficiency of knowledge production in OECD countries. Adoption of single bootstrap procedure described by Simar \& Wilson (2002) enabled the assessment of the impact of the regulatory environment on $\mathrm{R} \& \mathrm{D}$ efficiency. It has been proved that limited competition, enhanced by existing regulatory entry barriers, reduces R\&D efficiency because of ineffective resource allocation and erosion of incentives to innovate due to absence of competitive pressure from the side of new market entrants. Abbasi et al. (2010) established a DEA-based virtual index consisting of three input and four output indicators for the purposes of measuring relative innovativeness of 42 countries, including Egypt. Efficiency of NIS was assessed using a multi-stage virtual benchmarking process to propose best and rational benchmark. Authors recognized possibility of improving efficiency of individual economies without additional inputs to NIS, while questioning positive impact of rapid increase in R\&D expenditures on overall efficiency. Cai (2011) studied efficiency of 22 countries, including BRICS and the G7, using NIS approach and new growth theory. Author pointed at several determinants of NIS efficiency, stressing considerable role of enterprise $\mathrm{R} \& \mathrm{D}$, but also appreciating other aspects, ie. natural resources, education system, governance, market environment, external links, ICT infrastructure, economies of scale. The three latter determinants were considered by author as critical in respect of knowledge and technology diffusion. In case of BRICS economies, relatively high diversity of NIS performances was indicated. While China and India were ranked relatively high, poorer result of South Africa was associated with underdeveloped ICT infrastructure and limited enterprise R\&D. All five emerging markets were recognized as natural resource-dependent, with poor quality of governance and a threat related to the middle-income trap. Thus, Cai (2011) underlined the role of reforms to reorient those countries toward innovation-driven growth model. Chen et al. (2011), using a dataset for 24 economies with output-oriented indicators, recognized similarities among economies in terms of R\&D efficiency in patents and royalties, with diversity in respect of journal publications. An improvement of R\&D efficiency index was also confirmed in the field of enterprise R\&D funded by domestic and foreign private business sector in terms of royalties, licensing fees and patents. On the other hand, the journal-oriented R\&D efficiency index proved to be positively impacted by the R\&D intensity of higher education institutions. Guan \& Chen (2012) measured the efficiency of NIS in 22 countries using a relational network DEA model, with the adoption of two-stage innovation production framework, involving an upstream knowledge production process (KPP) and a downstream knowledge commercialisation process (KCP). Adopting a second-step partial least squares regression (PLSR), authors analysed the influence of policy-based institutional environment on innovation efficiency. In case of most OECD countries, a non-coordinated relationship between upstream R\&D efficiency and downstream commercialisation efficiency was detected, which resulted in significant rank 
differences. Authors confirmed the impact of downstream commercialisation efficiency performance on the overall innovation efficiency of NIS. Therefore, the future innovationoriented policies of OECD countries should focus on this component of innovation production network at first. The paper provided a set of policy recommendations resulting of partial least squares regression analysis, including adoption of more stage-specific innovation policies, oriented on strengthening the protection of intellectual property rights, financing R\&D and enhancing market-driven innovation. Dobrzanski (2018) investigated 20 countries, including Central and Eastern European (CEE) countries. Among CEE countries, Romania and Slovakia were the closest to efficiency frontier, however, hypothesis as to non-proportional results of increase in R\&D spendings was confirmed for CEE countries, but not for Western European countries. Therefore, author opted for a more gradual increase in R\&D spending to enhance innovation-driven economic growth, concerning the problem of limited capacities of CEE countries to achieve satisfactory innovation output. In his other study of efficiency of R\&D expenditures, Dobrzanski (2020) assessed 15 Latin American countries, indicating their relative underperformance in this respect. Low level of investment in R\&D translates into low productivity of science and technology, then, a small number of patents and publications, low shares of high-tech and ICT products in total exports. Results of R\&D expenditures and their increase in individual countries proved to be non-proportional. Taking into account limited capacities of regional economies in terms of transforming $R \& D$ expenditures to innovation outputs, author recommended gradual increase in $\mathrm{R} \& \mathrm{D}$ spending in order to establish conditions favouring innovation-driven growth. Dobrzanski \& Bobowski (2020) analysed the efficiency of R\&D spendings in 15 ASEAN and Asia-Pacific countries, using VRS and CRS output-oriented DEA models. When adopting the constant return to scale (CRS) approach, Hong Kong and the Philippines proved to be the most efficient in respect of $R \& D$, however, variable return to scale (VRS) approach enabled to identify another two ASEAN countries operating in the efficiency frontier, ie. Indonesia and Singapore. Authors recognized non-proportional effects of R\&D expenditures among analysed countries - a good example is South Korea, in case of which relatively high R\&D expenditures did not translate into high ranking in CRS model. On the other hand, Hong Kong, with relatively lower R\&D expenditures when compared to Singapore or South Korea, benefit from positive non-intervention policy and solid innovation base fuelled by smaller enterprises. Authors, taking into consideration limited innovative capacities of the studied ASEAN and the Asia-Pacific countries, opted for gradual increase in R\&D expenditures to pave the way toward innovation-driven growth. Sinimole \& Saini (2020) studied 25 Asian countries using output-oriented DEA model, divided into two groups: countries which spend less than $1 \%$ of GDP on R\&D and those, which spend 1\% or more. Only two countries from the second group operated in the efficiency frontier, e.g. Israel and Singapore, while among countries classified to the first group there were five, including Bahrain, Armenia and Vietnam. Authors stressed the importance of several parameters such as 'ease of doing business' strategies, trade and regulatory policies, industry-academia collaboration and public-private partnership in respect of stimulating efficiency of R\&D expenditures. 


\section{RESEARCH OBJECTIVE, METHODOLOGY AND DATA}

The aim of the article is to verify whether R\&D funds were used efficiently in African countries. In order to calculate the efficiency indicator, DEA methodology is employed. This methodology, firstly presented by Farrell (1957) and further extensions are done by Charnes et al. (1978), is a non-parametric methodology that relies on linear programming benchmarking to assess the decision-making units (DMUs) relative efficiency. Relative efficiency is measuring the relation between the weighted sum of outputs and the weighted sum of inputs. DEA allows constructing the production frontier which serves as the benchmark for efficiency measures (Cooper et al., 2000). However, it is worth highlighting that in DEA methodology, efficient DMUs are bestpractice frontiers from the analyzed group (Cook et al., 2014). In DEA methodology, efficiency is not an absolute measure, as DMUs classified as efficient are able to further improve their performance. Instead, DEA provides a measure of relative technical efficiency.

DEA methodology was selected for the analysis of R\&D efficiency because of its numerous advantages. DEA does not need information regarding the importance of particular inputs and outputs in the evaluation procedure (Wober, 2007), as well as defining the mathematical function of the effectiveness (Thanassoulis, 2003); therefore, it can be used for the analysis of processes where the relationship between inputs and outputs is unknown. DEA requires only few assumptions about the properties of the production possibilities set in estimating technical efficiency compared to the parametric approach such as a stochastic frontier approach (Setiawan et al., 2012). DEA is a flexible method and can be used in the model of structure is not established a priori, but is adapted to the data (Dobrzanski, 2017). Moreover, DEA models enable the analysing of multiple outputs and inputs and causes of inefficiency. Also, the inputs and outputs can be measured in different units, which is the case in the selected dataset. However, there are a few limitations of DEA methodology, which should be considered when interpreting results. One of the main DEA limitations is that it does not include qualitative variables, and therefore, some important factors may be excluded from the analysis. Zhang \& Bartels (1998) also pointed out a decrease in efficiency with an increase in the number of DMUs. Therefore, careful interpretation and sensitivity analysis are required.

DEA models can be divided into two groups: output- or input-oriented. In the output-oriented extensions efficiency, there is a proportionate growth in outputs with the input unchanged. Analogously, in an input-oriented model, efficiency is a proportionate decrease in input, with outputs unchanged (Thanassoulis, 2001). DEA models can also be divided into a variable return to scale (VRS) or a constant return to scale (CRS). As the interpretation of VRS is much more composite, it is usually used only to control increasing or decreasing returns (Kao \& Liu, 2011).

The CRS efficiency indicator is calculated with the below Equations 1-2 (Charnes et al., 1978):

$\operatorname{Max} \theta_{0}=\frac{\sum_{\mathrm{s}=1}^{\mathrm{S}} \mathrm{u}_{\mathrm{r}} \mathrm{y}_{\mathrm{rj}}}{\sum_{\mathrm{m}=1}^{\mathrm{M}} \mathrm{v}_{\mathrm{m}} \mathrm{x}_{\mathrm{mj}}}$,

subject to:

$\frac{\sum_{\mathrm{s}=1}^{\mathrm{S}} \mathrm{u}_{\mathrm{r}} \mathrm{y}_{\mathrm{rj}}}{\sum_{\mathrm{m}=1}^{\mathrm{M}} \mathrm{v}_{\mathrm{m}} \mathrm{x}_{\mathrm{mj}}} \leq 1$, 
$\mathrm{u}_{\mathrm{r} \infty}, \mathrm{v}_{\mathrm{m}} \geq 0 ; \mathrm{s}=1, \ldots, \mathrm{S} ; \mathrm{m}=1, . ., \mathrm{M}$

where:

$u_{s}$-weight of output

$v_{m}$ - weight of input

$y_{1 j}$ - output

$x_{m j}$ - input

The VRS extension requires an additional constraint equation (Simar \& Wilson, 2002):

$\sum \mathrm{n}_{\mathrm{i}=1} \lambda \mathrm{j}=1$

where $\mathrm{n}$ is the number of DMUs and $\lambda$ is the corresponding solution vector for the optimisation.

In DEA, the weights are chosen in a manner that assigns a set of weights to each DMU to maximized efficiency under the given data. Thus, the weights differ across DMUs. If additional knowledge (e.g. expert knowledge) about the importance of individual inputs and outputs exist, then restrictions need to be placed on weights in DEA (Lee et al., 2009). There is a large diversity of weights restriction methods. However, in this case, we weight restrictions were not applied, as there is no unequivocal evidence, which of the analyzed variables are more important than others.

To evaluate the variation in the efficiency indicator over the research period, Malmquist index is used, which allows measuring the proportion of each DMU efficiencies in two selected time periods. The Malmquist index consists of two components: efficiency change (change in distance from maximum potential between the two periods) and technical change (shift in technology between the two periods). The Malmquist index was used to evaluate change in the relevant performance and impact of efficiency and technological components on efficiency variation. Using equation 4, the Malmquist index could be calculated (Fare \& Grosskopf, 1992):

$$
M_{o}\left(x^{t+1}, y^{t+1}, x^{t}, y^{t}\right)=\frac{D_{o}^{t+1}\left(x^{t+1}, y^{t+1}\right)}{D_{o}^{t}\left(x^{t}, y^{t}\right)} x \sqrt{\left(\frac{D_{o}^{t}\left(x^{t+1}, y^{t+1}\right)}{D_{o}^{t+1}\left(x^{t+1}, y^{t+1}\right)}\right)\left(\frac{D_{o}^{t}\left(x^{t}, y^{t}\right)}{D_{o}^{t+1}\left(x^{t}, y^{t}\right)}\right)}
$$

The authors have chosen data from the World Bank based on availability and comparability criteria. Firstly, for the analysis, all African economies included in the World Development Indicators statistics (World Bank, 2020) were selected. Then among the selected countries, those for which innovation indicators were available were chosen. According to the same rule the research period was chosen. In total, 12 countries for the period of 2009-2017 were analyzed.

Efficiency calculations are performted in DEAFrontier and Malmquist Index Software. The input indicator is represented by RDE - annual public and private spending on innovation (as \% of GDP). Three output indicators were selected for the analysis: patent applications (PA), hightechnology exports (HTE) and scientific and technical journal articles (STJA). (for details, see Table 2). 
Tab. 2 - Indicators and Sources. Source: World Bank (2020a - 2020f)

\begin{tabular}{|c|c|c|c|}
\hline Variable & Indicator name & Units & Source \\
\hline Input - RDE & $\begin{array}{l}\text { The annual public and } \\
\text { private spending on } \\
\text { innovation }\end{array}$ & $(\%$ GDP $)$ & World Bank, 2020a \\
\hline Output 1 - PA & $\begin{array}{l}\text { Number of residents } \\
\text { and non-residents patent } \\
\text { applications per mln } \\
\text { inhabitants }\end{array}$ & $\begin{array}{l}\text { (Per million } \\
\text { inhabitants) }\end{array}$ & $\begin{array}{l}\text { World Bank, 2020b; } \\
\text { World Bank, 2020c; } \\
\text { World Bank, 2020d }\end{array}$ \\
\hline Output 2 - HTE & $\begin{array}{l}\text { Exports of high-tech } \\
\text { products }\end{array}$ & ( $\%$ of exports) & World Bank, 2020e \\
\hline Output 3 - STJA & $\begin{array}{l}\text { Scientific and technical } \\
\text { journal articles per mln } \\
\text { inhabitants }\end{array}$ & $\begin{array}{l}\text { (Per million } \\
\text { inhabitants) }\end{array}$ & $\begin{array}{l}\text { World Bank, 2020f; } \\
\text { World Bank, 2020d }\end{array}$ \\
\hline
\end{tabular}

\section{RESULTS AND DISCUSSION}

The authors have chosen to assess the input-oriented model as most of the national innovation strategies assume an optimal input level of R\&D spending as a percentage of GDP, most of the national strategies focus more on input rather than output. To provide a more general analytical framework, the authors adapted both the VRS and the CRS methodology. R\&D activity can exhibit increasing or decreasing returns to scale as well as constant returns to scale. Most of the studies presented in the literature review used VRS assumption. CRS models require the assumption of full proportionality between all inputs and outputs. However, sometimes a subset of outputs may be proportional to a subset of inputs and when VRS model is used, this information is effectively ignored and the efficiency is overestimated (Cai, 2011). To avoid such situation, the authors used a dual approach and calculated the average efficiency index and ranking.

The authors calculated the efficiency of spending on R\&D for nine years (2009-2017). The results of this analysis are presented in Tables 3 and 4 .

Tab. 3 - Input-Oriented CRS Efficiency of R\&D Spending in 2009-2017. Source: own research

\begin{tabular}{|l|l|l|l|l|l|l|l|l|l|l|l|l|}
\hline & CSR & 2009 & 2010 & 2011 & 2012 & 2013 & 2014 & 2015 & 2016 & 2017 & Avg. & Rank \\
\hline 1 & BWA & 0.61 & 0.62 & 0.61 & 0.56 & 0.27 & 0.27 & 0.20 & 0.24 & 0.24 & 0.40 & 7 \\
\hline 2 & DZA & 0.37 & 0.33 & 0.34 & 0.36 & 0.36 & 0.34 & 0.34 & 0.28 & 0.32 & 0.34 & 9 \\
\hline 3 & EGY & 0.51 & 0.51 & 0.40 & 0.43 & 0.32 & 0.32 & 0.27 & 0.22 & 0.32 & 0.37 & 8 \\
\hline 4 & GHA & 0.48 & 0.59 & 0.09 & 0.11 & 0.42 & 0.23 & 0.26 & 0.15 & 0.31 & 0.29 & 11 \\
\hline 5 & KEN & 0.33 & 0.51 & 0.06 & 0.06 & 0.17 & 0.12 & 0.15 & 0.07 & 0.11 & 0.18 & 12 \\
\hline 6 & MDG & 0.57 & 1.00 & 0.16 & 0.21 & 0.50 & 1.00 & 0.72 & 1.00 & 1.00 & 0.68 & 4 \\
\hline 7 & MOZ & 1.00 & 0.33 & 0.02 & 0.02 & 1.00 & 0.45 & 1.00 & 0.07 & 0.94 & 0.54 & 5 \\
\hline
\end{tabular}




\begin{tabular}{|l|l|l|l|l|l|l|l|l|l|l|l|l|}
\hline 8 & MUS & 1.00 & 0.91 & 0.71 & 0.93 & 0.99 & 0.97 & 0.90 & 1.00 & 1.00 & 0.93 & 3 \\
\hline 9 & NAM & 0.81 & 1.00 & 0.28 & 0.26 & 0.35 & 0.30 & 0.24 & 0.27 & 0.25 & 0.42 & 6 \\
\hline 10 & TUN & 1.00 & 1.00 & 1.00 & 1.00 & 1.00 & 1.00 & 1.00 & 1.00 & 1.00 & 1.00 & 1 \\
\hline 11 & UGA & 0.17 & 0.55 & 0.08 & 0.10 & 0.87 & 0.39 & 0.40 & 0.21 & 0.28 & 0.34 & 9 \\
\hline 12 & ZAF & 1.00 & 1.00 & 1.00 & 1.00 & 1.00 & 1.00 & 1.00 & 1.00 & 1.00 & 1.00 & 1 \\
\hline
\end{tabular}

Note: BWA - Botswana, DZA - Algeria, EGY - Egypt, GHA - Ghana, KEN - Kenya, MGD - Madagascar, MOZ - Mozambique, MUS - Mauritius, NAM - Namibia, TUN - Tunisia, UGA - Uganda, ZAF - South Africa

Tab. 4 - Input-Oriented VRS Efficiency of R\&D Spending in 2009-2017. Source: own research

\begin{tabular}{|l|l|l|l|l|l|l|l|l|l|l|l|l|}
\hline & VSR & 2009 & 2010 & 2011 & 2012 & 2013 & 2014 & 2015 & 2016 & 2017 & Avg. & Rank \\
\hline 1 & BWA & 0.74 & 0.75 & 0.89 & 0.64 & 0.30 & 0.28 & 0.21 & 0.26 & 0.26 & 0.48 & 8 \\
\hline 2 & DZA & 0.40 & 0.39 & 0.42 & 0.39 & 0.37 & 0.35 & 0.35 & 0.29 & 0.33 & 0.37 & 11 \\
\hline 3 & EGY & 0.53 & 0.54 & 0.48 & 0.45 & 0.33 & 0.32 & 0.27 & 0.23 & 0.32 & 0.39 & 10 \\
\hline 4 & GHA & 0.59 & 0.68 & 0.33 & 0.23 & 0.44 & 0.53 & 0.27 & 0.21 & 0.40 & 0.41 & 9 \\
\hline 5 & KEN & 0.36 & 0.54 & 0.16 & 0.11 & 0.18 & 0.28 & 0.16 & 0.35 & 0.13 & 0.25 & 12 \\
\hline 6 & MDG & 1.00 & 1.00 & 1.00 & 1.00 & 1.00 & 1.00 & 1.00 & 1.00 & 1.00 & 1.00 & 1 \\
\hline 7 & MOZ & 1.00 & 0.35 & 0.28 & 0.17 & 1.00 & 1.00 & 1.00 & 0.25 & 1.00 & 0.67 & 5 \\
\hline 8 & MUS & 1.00 & 1.00 & 1.00 & 1.00 & 1.00 & 0.98 & 0.93 & 1.00 & 1.00 & 0.99 & 4 \\
\hline 9 & NAM & 1.00 & 1.00 & 0.60 & 0.40 & 0.40 & 0.56 & 0.26 & 0.46 & 0.26 & 0.55 & 7 \\
\hline 10 & TUN & 1.00 & 1.00 & 1.00 & 1.00 & 1.00 & 1.00 & 1.00 & 1.00 & 1.00 & 1.00 & 1 \\
\hline 11 & UGA & 0.40 & 0.66 & 0.37 & 0.30 & 1.00 & 0.84 & 0.42 & 0.68 & 0.35 & 0.56 & 6 \\
\hline 12 & ZAF & 1.00 & 1.00 & 1.00 & 1.00 & 1.00 & 1.00 & 1.00 & 1.00 & 1.00 & 1.00 & 1 \\
\hline
\end{tabular}

The final efficiency index was calculated based on the results from Table 3 and Table 4. Then, the efficiency ranking was made, which is the presented in Table 5. According to the presented ranking, Tunisia and South Africa are the most efficient countries which were efficient in the whole analyzed period in both VRS and CRS. Madagascar (1.00) is an efficiency frontier in VRS model; however, this economy was placed 3rd in the ranking due to obtaining worse results under the CRS model. Five out of twelve economies gained the score higher than the average 0.589: Tunisia, South Africa, Madagascar, Mauritius and Mozambique. Remaining seven economies gained scores lower than the average efficiency index: Namibia, Uganda, Botswana, Egypt, Algeria, Ghana, Kenya. Kenya's lowest place in the ranking may be unexpected as this country spends relatively more than other countries in the Africa region on research and development. The hypothesis about the non-proportional relation between higher R\&D spending and innovation outputs has not been confirmed. Moreover, it is important to underline that the DEA methodology estimates relative efficiency and examines the degree to which research and development funds have been converted into innovation outputs. 
Tab. 5 - Efficiency Ranking for African countries. Source: own research

\begin{tabular}{|l|l|l|l|l|}
\hline Countries & AVG CRS Index & AVG VRS Index & AVG Index & Rank \\
\hline TUN & 1.000 & 1.000 & 1.000 & 1 \\
\hline ZAF & 1.000 & 1.000 & 1.000 & 1 \\
\hline MUS & 0.934 & 0.991 & 0.962 & 3 \\
\hline MDG & 0.684 & 1.000 & 0.842 & 4 \\
\hline MOZ & 0.537 & 0.672 & 0.604 & 5 \\
\hline NAM & 0.418 & 0.548 & 0.483 & 6 \\
\hline UGA & 0.338 & 0.557 & 0.448 & 7 \\
\hline BWA & 0.403 & 0.479 & 0.441 & 8 \\
\hline EGY & 0.365 & 0.385 & 0.375 & 9 \\
\hline DZA & 0.338 & 0.366 & 0.352 & 10 \\
\hline GHA & 0.294 & 0.409 & 0.351 & 11 \\
\hline KEN & 0.175 & 0.252 & 0.214 & 12 \\
\hline AVG for African countries & 0.540 & 0.638 & 0.589 & \\
\hline
\end{tabular}

Moreover, the Malmquist productivity index was estimated with both efficiency change (EC) and technical change (TC) components. The adjacent-base calculation method was used by the authors for each country annually using time moment (MI $\left(\mathrm{t} \_1 \mathrm{t} \_2\right), \mathrm{MI}\left(\mathrm{t} \_2 \mathrm{t} \_3\right)$...MI(t_(N-1) t_N)). Table 6 presents the results for the years 2009-2017. The values of Malmquist index above one can be interpreted as an improvement in the relevant performance, while the values below one represent a decrease in performance.

Tab. 6 - Malmquist Index 2009-2017 ( $\mathrm{t}$ and $\mathrm{t}+1$ ). Source: own research

\begin{tabular}{|l|l|l|l|l|l|l|l|l|l|l|}
\hline & $2009 / 10$ & $10 / 11$ & $11 / 12$ & $12 / 13$ & $13 / 14$ & $14 / 15$ & $15 / 16$ & $16 / 17$ & EC & TC \\
\hline BWA & 1.09 & 1.02 & 0.97 & 0.53 & 1.09 & 0.82 & 1.33 & 0.98 & 9.20 & 7.84 \\
\hline DZA & 0.98 & 1.11 & 1.10 & 1.03 & 0.99 & 1.04 & 0.98 & 1.01 & 8.13 & 8.20 \\
\hline EGY & 1.11 & 0.84 & 1.10 & 0.78 & 1.02 & 0.88 & 1.03 & 1.15 & 8.01 & 8.10 \\
\hline GHA & 0.55 & 0.91 & 2.51 & 0.76 & 0.74 & 0.80 & 0.73 & 2.37 & 10.76 & 11.02 \\
\hline GMB & 0.24 & 1.87 & 0.47 & 3.45 & 0.17 & 0.84 & 2.84 & 0.35 & 10.68 & 8.87 \\
\hline KEN & 1.24 & 0.64 & 0.93 & 0.93 & 0.93 & 0.95 & 0.98 & 0.97 & 10.77 & 9.97 \\
\hline MOZ & 0.13 & 19.47 & 1.00 & 0.56 & 0.44 & 2.06 & 0.14 & 7.01 & 10.29 & 14.63 \\
\hline MUS & 0.84 & 0.84 & 1.34 & 1.11 & 1.03 & 0.99 & 1.44 & 0.95 & 8.50 & 8.13 \\
\hline NAM & 0.88 & 0.73 & 1.39 & 0.67 & 1.18 & 0.49 & 2.23 & 0.63 & 9.34 & 8.79 \\
\hline TUN & 1.11 & 1.07 & 1.03 & 1.09 & 1.07 & 1.13 & 1.05 & 0.98 & 8.60 & 8.10 \\
\hline UGA & 1.63 & 11.00 & 1.24 & 0.47 & 0.55 & 0.79 & 0.99 & 0.98 & 15.22 & 13.86 \\
\hline ZAF & 1.04 & 1.12 & 1.03 & 1.00 & 0.98 & 0.96 & 0.94 & 1.01 & 8.00 & 8.07 \\
\hline Mean & 0.90 & 3.38 & 1.17 & 1.03 & 0.85 & 0.98 & 1.22 & 1.53 & 9.79 & 9.63 \\
\hline EC & 24.52 & 11.71 & 12.92 & 12.68 & 15.74 & 9.09 & 19.39 & 11.45 & 117.49 & 115.57 \\
\hline
\end{tabular}




\begin{tabular}{|l|l|l|l|l|l|l|l|l|l|l|}
\hline TC & 6.42 & 30.66 & 13.09 & 11.57 & 8.82 & 16.12 & 10.02 & 18.87 & 115.57 & - \\
\hline
\end{tabular}

Based on equation (4), the Malmquist index has been calculated, with the results presented in Table 6. Nine out of twelve African economies are efficient, with an average increase of 38.4 $\%$ yearly. Mozambique achieved the highest average growth. Among the three inefficient economies, Kenya demonstrated the most significant decline in productivity $(-5.4 \%)$. The presented results also show that the efficiency change is slightly more important than technology change in increasing the overall productivity in 8 out of 12 analyzed countries.

\section{CONCLUSION}

This analysis delivers new empirical material in the form of a comparative study of African countries, which enables researchers to study the innovation gap and attempts to complement previous analyses dedicated to developing economies and their experience in respect of science, technology and innovation policies. Despite many efforts across African economies, significant obstacles stand in the way of increasing their innovation level and enhancing their development. The fundamental problem is inadequate and inefficient spending on R\&D. Among African countries, the most efficient ones are South Africa and Tunisia, which implemented their first NIS a decade ago, followed by Mauritius, also placing itself close to the efficiency frontier. A disappointing result is achieved by Kenya, even though it spends $0.79 \%$ of GDP on R\&D. In general, the empirical analysis indicated the relative underperformance of the African countries in respect of innovation efficiency; however, the results of low expenditures on $\mathrm{R} \& \mathrm{D}$ proved to be disproportional. With the application of the Malmquist index, it has become possible to confirm that the overall productivity change is impacted to a slightly larger extent by efficiency change than technology change. Considering the limited innovation capacities across the African countries, it appears to be reasonable to increase R\&D expenditures gradually to achieve better results on the path toward innovation-driven growth and development. This finding is in line with the results obtained by Dobrzanski \& Bobowski (2020) and Dobrzanski (2018, 2020). However, contrary to the studied cases of Central and Eastern Europe, Latin America, as well as selected Asia-Pacific and ASEAN countries, in case of African countries an increase in R\&D expenditures resulted in their higher efficiency. The only exception was Kenya with its relatively high R\&D expenditures in relation to GDP although a low ranking in terms of efficiency. The specificity of the results obtained for African countries results in the fact that in most cases R\&D expenditures accounted for no more than 1\% of GDP. This analysis found South Africa operating in the efficiency frontier, a result which contrasts with the study of Nasierowski \& Arcelus (2003) in which this country was assessed as inefficient and overinvested in respect of R\&D. These conflicting results are a consequence of a number of factors, i.e. the different methodological approaches and the set of variables determined by their availability in case of African economies, as well as the fact that in our study South Africa is compared with lower-developed African countries, while in case of the analysis of Nasierowski \& Arcelus (2003) the nation is compared with several higher-developed countries such as Japan, South Korea, Australia and Taiwan.

As noted by the authors, a large diversity among African countries exists in terms of the institutionalization of STI policies. Even though most of the countries have already developed 
legal frameworks in this field, in the past these took the form of a set of separate programs and documents, rarely a single strategy or plan of action. As a result, a poor connection has been made between innovation and ST policies along with their ineffective implementation. Further, unsuccessful implementation has been correlated with a low quality of governance and ICT infrastructure as well as a low level of enterprise R\&D. All of this concurs with the findings of Cai (2011) in respect to the drawbacks of NIS across developing and emerging markets which hinder knowledge and technology diffusion. The importance of institutional frameworks in terms of enhancing innovation efficiency and the non-proportional effects of increases in $R \& D$ expenditures was reflected in our case in the differences in ranking across African countries, with our results concurring with studies dedicated to OECD countries by Guan \& Chen (2012).

In it aspirations become an innovation hub and to address development challenges, Africa is attempting to build innovation policy on a continental scale. Intra- and extra-regional coordination of the STI policies of African countries has proven to be critical in solving the problem of limited state capacity and ineffective links between public institutions/government and private sector/ industry in terms of, on one hand, communicating needs and, on the other, providing solutions in the form of knowledge and innovation. While eight RECs appeared to lack sufficient political entrepreneurship in this field, continent-wide agencies and bodies such as AMCOST, established under the auspices of AUDA-NEPAD (2019) and the AU, have attempted to build the foundations of a system of monitoring and data collection regarding national innovation systems across African countries. The ASTII and AUDA-NEPAD (2019) have established a set of key indicators for tracking the implementation of STISA 2024, enabling the harmonization of statistics, STI policies and monitoring across the continent in compliance with the Sustainable Development Goals and Agenda 2063. Among potential continent-wide initiatives, R\&D platforms and databases aim to promote and exchange results by regional innovation agencies and institutions; innovation surveys for the usage of innovation infrastructure across African Member States (AMS); and the coordination of scholarship/subsidies/grant schemes, training and education programs focusing on R\&D across AMS. The main goal of these actions is to spur lower-developed AMS to launch NIS. Moreover, there is a necessity of liberalization and the deregulation of services, goods and capital flow to promote R\&D expenditures under the pressure of international competition. Additionally, knowledge spillover can be achieved by the free movement of people. Thus, there is a necessity to improve regulations on engineering services and enhancing collaboration of the higher education sector across Africa. This would be a task for RECs, as well as the aforementioned continent-wide agencies and organizations.

Our research has some limitations, with the major one being the extremely limited accessibility of innovation data for Africa. Only basic innovation statistics for a select group of countries is available. Nowadays, international institutions have access to more reliable databases of innovation input indicators, covering among other parameters R\&D infrastructure and staff, knowledge stock and innovative enterprises. Another challenge is the estimation of innovative outcomes and the accurate time lag between inputs and outputs. Using more reliable innovation, inputs and outputs statistics could facilitate more credible conclusions and deliver a more holistic picture of the efficiency of the innovation process within the economy. Furthermore, conducting research on longer ranges of data could result in more useful conclusions and recommendations for policymakers in the field of innovation. 


\section{Funding:}

The project is financed by the Ministry of Science and Higher Education in Poland under the program "Regional Initiative of Excellence" 2019-2022, project number 015/RID/2018/19, total funding amount PLN 10721040.00 .

\section{Acknowledgements}

We would like to thank the chairperson, Dr Kameliia Petrova from the State University of New York Plattsburgh, as well as the seminar participants at the Joint International Conference of CEDIMES Institute the USA, Africa Business and Entrepreneurship Research Society and IPAGEF (Plattsburgh, New York, USA, Friday-Sunday, 30th August - 1st September 2019) for useful comments. We also feel grateful to Professor Pete Tyler (University of Cambridge) for hosting me at the University of Cambridge as a Visiting Scholar as well as to Professor Philip Arestis (University of Cambridge), Professor Alan Barrell (Cambridge Learning Gateway), and Professor Leon Olszewski (University of Wroclaw) for their helpful comments and suggestions.

\section{References}

1. Abbasi, F., Hajihoseini, H., \& Haukka, S. (2010). Use of Virtual Index for Measuring Efficiency of Innovation Systems: A Cross-Country Study. International Journal of Technology Management and Sustainable Development, 9, 195-212.

2. AfDB (2020). African Economic Outlook 2020, African Development Bank, Abidjan. https:// www.afdb.org/en/documents/african-economic-outlook-2020

3. Afzal, M., Lawrey, R., \& Gope, J. (2019). Understanding national innovation system (NIS) using porter's diamond model (PDM) of competitiveness in ASEAN-05. Competitiveness Review: An International Business Journal. 29 (4), 336-355. https://doi.org/10.1108/CR-12-2017-0088

4. AUDA-NEPAD (2019). African Innovation Outlook 2019. African Union Development Agency, Johannesburg. Retreived from: https://au.int/sites/default/files/documents/38122doc-aio_3rd_edition_final_eng_repro.pdf

5. Blanco, L., Gu, R.J., \& Prieger, J.E. (2016). The Impact of Research and Development on Economic Growth and Productivity in the U.S. States. Southern Economic Journal, 82 (3), 914-934, https://doi.org/10.1002/soej.12107

6. Cai, Y. (2011). Factors Affecting the Efficiency of the BRICS' National Innovation Systems: A Comparative Study Based on DEA and Panel Data Analysis; Kiel Institute for the World Economy, Kiel.

7. Charnes, A., Cooper, W. W., \& Rhodes, E. (1978). Measuring the efficiency of decision making units. European Journal of Operational Research, 2 (6), 429_444, https://doi.org/10.1016/03772217(78)90138-8

8. Chen, C. P., Hu, J. L. \& Yang, C. H. (2011). An international comparison of R\&D efficiency of multiple innovative outputs: The role of the national innovation system. Innovation: Management, Policy \& Practice, 13(3), 341-360.

9. Clark, J., \& Guy, K. (1998). Innovation and competitiveness: a review. Technology Analysis \& Strategic Management, 10 (3), 363-395.

10. Cook, W. D., Tone, K., \& Zhu, J. (2014). Data envelopment analysis: Prior to choosing a model. Omega, 44, 1-4, http://dx.doi.org/10.1016/j.omega.2013.09.004

11. Cooper, W. W., Seiford, L. M., \& Tone, K. (2000). Data Envelopment Analysis: A Comprehensive Text with Models, Applications, References and DEA-Solver Software. Boston: Kluwer Academic Publishers. 
12. Cullmann, A., Schmidt-Ehmcke, J., \& Zloczysti, P. (2009). Innovation, R\&D Efficiency and the Impact of the Regulatory Environment: A Two-Stage Semi-Parametric DEA Approach, Discussion Papers of DIW Berlin 883, DIW Berlin, German Institute for Economic Research.

13. Dobrzanski, P. (2017). Spending on Innovation as a Factor of Competitiveness of Market Economies. Bilgin M., Danis H., Demir E., Can U. (eds) Country Experiences in Economic Development, Management and Entrepreneurship. Eurasian Studies in Business and Economics, 5, Springer, Cham, https://doi.org/10.1007/978-3-319-46319-3_7

14. Dobrzanski, P. (2020). The efficiency of spending on R\&D in Latin America region. Applied Economics, 52 (46), 5020-5034. https://doi.org/10.1080/00036846.2020.1752900

15. Dobrzanski, P. (2018). Innovation expenditures efficiency in Central and Eastern European Countries. Zbornik Radova Ekonomskog Fakulteta u Rijeci-Proceedings of Rijeka Faculty of Economics, 36 (2), 827-859. doi.org/10.18045/zbefri.2018.2.827

16. Dobrzanski, P., \& Bobowski, S. (2020). The Efficiency of R\&D Expenditures in ASEAN Countries. Sustainability, 12(7), 2686. https://doi.org/10.3390/su12072686

17. Fare, R., \& Grosskopf S. (1992). Malmquist Productivity Indexes and Fisher Ideal Indexes. Economic Journal, 158-160.

18. Farrell, M. J. (1957). The measurement of productive efficiency. Journal of the Royal Statistical Society, 120 (3), 253-290, https://doi.org/10.2307/2343100

19. Guan, J., \& Chen, K. H. (2012). Modeling the relative efficiency of national innovation systems. Research Policy, 41, 102-115.

20. Guellec, D., \& Potteri, B. P. (2004). From R\&D to Productivity Growth: Do the Institutional Settings and the Source of Funds of R\&D Matter? Oxford Bulletin of Economics and Statistics, 66 (3), 353-378, https://doi.org/10.1111/j.1468-0084.2004.00083.x

21. Kao, C., \& Liu, S. T. (2011). Efficiencies of Two-Stage Systems with Fuzzy Data. Fuzzy Sets and Systems, 176, 20-35, https://doi.org/10.1016/j.fss.2011.03.003

22. Kaur, M., \& Singh, L. (2016). R\&D Expenditure and Economic Growth: An Empirical Analysis. International Journal of Technology Management and Sustainable Development, 15 (3), 195-213, https://doi.org/10.1386/tmsd.15.3.195_1

23. Lall, S., \& Pietrobelli, C. (2005). National technology systems in sub-Saharan Africa. International Journal of Technology and Globalisation, 1 (3), 311-342.

24. Lee, H., Park, Y., \& Choi, H. (2009). Comparative evaluation of performance of national R\&D programs with heterogeneous objectives: A DEA approach. European Journal of Operational Research, 196 (3), 847-855. https://doi.org/10.1016/j.ejor.2008.06.016

25. Muchie, M., Gammeltoft, P., \& Lundvall, B. A. (2003). Putting Africa first: the making of African innovation systems. Aalborg Universitetsforlag.

26. Nasierowski,W., \& Arcelus, F. J. (2003). On the efficiency of national innovation systems. Socio-Economic Planning Sciences, 37 (3), 215-234.

27. NPCA (2014). African Innovation Outlook 2014. NEPAD Planning and Coordinating Agency, Pretoria. https://www.nepad.org/publication/african-innovation-outlook-ii 
28. OECD (2010). Ministerial Report on the OECD Innovation Strategy, Organization for Economic Cooperation and Development. http://www.oecd.org/sti/45326349.pdf

29. Setiawan, M., Emvalomatis, G., \& Oude Lansink, A. (2012). The relationship between technical efficiency and industrial concentration: evidence from the Indonesian food and beverages industry. Journal of Asian Economics, 23 (4), 466-475.

30. Simar, L., \& Wilson, P. (2002). Nonparametric tests of returns to scale. European Journal of Operational Research, 139, 115-132.

31. Sinimole, K. R., \& Saini, K. M. (2020). Performance evaluation of R\&D organizations: an Asian perspective. International Journal of the Economics of Business. https://doi.org/10.1080/13571 516.2020 .1858703

32. Sokolov-Mladenović, S., Cvetanović, S. \& Mladenović, I. (2016). R\&D Expenditure and Economic Growth: EU 28 Evidence for the Period 2002-2012. Economic Research - Ekonomska Istraivanja, 29 (1), 1005-1020. https://doi.org/10.1080/1331677X.2016.1211948

33. Thanassoulis E. (2001). Using Data Envelopment Analysis in Practice. Introduction to the Theory and Application of Data Envelopment Analysis. Springer, Boston, MA. https://doi.org/10.1007/978-14615-1407-7_5

34. Thanassoulis, E. (2003). Introduction to the Theory and Application of Data Envelopment Analysis. Norwell: Kluwer Academic Publishers. https://doi.org/10.1007/978-1-4615-1407-7

35. Wober, K. W. (2007). Data Envelopment Analysis. Journal of Travel \& Tourism Marketing, 21 (4), 91-108. https://doi.org/10.1300/j073v21n04_07

36. World Bank, World Development Indicators. (2020a). Research and development expenditure (\% of GDP). https://data.worldbank.org/indicator/GB.XPD.RSDV.GD.ZS

37. World Bank, World Development Indicators. (2020b). Patent applications, residents. https:// data.worldbank.org/indicator/IP.PAT.RESD

38. World Bank, World Development Indicators. (2020c). Patent applications, non-residents. https://data.worldbank.org/indicator/IP.PAT.NRES

39. World Bank, World Development Indicators. (2020d). Population, total. https://data. worldbank.org/indicator/SP.POP.TOTL

40. World Bank, World Development Indicators. (2020e). High-technology exports (\% of manufactured exports). https://data.worldbank.org/indicator/TX.VAL.TECH.MF.ZS

41. World Bank, World Development Indicators. (2020f). Scientific and technical journal articles. https://data.worldbank.org/indicator/IP.JRN.ARTC.SC

42. Zhang, Y., \& Bartels, R. (1998). The Effect of Sample Size on the Mean Efficiency in DEA with an Application to Electricity Distribution in Australia, Sweden and New Zealand. Journal of Productivity Analysis, 9 (3), 187-204. 


\section{Contact information}

Assist. prof. Pawel Dobrzanski, Ph.D.

Wroclaw University of Economics and Business, Poland

Faculty: Economics and Finance

Department (Institute): Mathematical Economics

Poland

E-mail:pawel.dobrzanski@ue.wroc.pl

ORCID: 0000-0002-3137-7797

Assoc. prof. Sebastian Bobowski, Ph.D.

Wroclaw University of Economics and Business, Poland

Faculty: Economics and Finance

Department (Institute): International Economic Relations

Poland

E-mail:sebastian.bobowski@ue.wroc.pl

ORCID: 0000-0002-1723-313X

prof. Elie Chrysostome, Ph.D.

State University of New York, Campus of Plattsburgh, USA

Faculty Directory for Supply Chain Management \& International Business

Department (Institute): Supply Chain Management \& International Business Department

USA

E-mail: chrysoev@plattsburgh.edu

ORCID: 0000-0002-0573-9969

Assist. prof. Emil Velinov, Ph.D.

ŠKODA AUTO University, Mladá Boleslav, Cžech Republic

Department (Institute): Marketing and Management

E-mail:emil.velinov@savs.cz.

RISEB A University of Applied Science, Riga, Latvia

Department (Institute): Business Studies

Plekhanov Russian University of Economics, Moscow, Russia

Department of Management Theory and Business Technologies

Crech Republic

E-mail:emil.velinov@riseba.lv

ORCID: 0000-0001-6073-1196

prof. Jiri Stroubal, Ph.D.

ŠKODA AUTO University, Mladá Boleslav, Cžech Republic

Department (Institute): Finance and Accounting

Czech Republic

E-mail:jiri.stroubal@savs.cz.

ORCID: 0000-0001-9109-7087 